\title{
KARAKTERISTIK DINAMIK ROTOR BOW THRUSTER 250 KW MENGGUNAKAN
} PEMODELAN EULER-BERNOULLI BEAM

\section{DYNAMIC CHARACTERISTICS OF 250 KW ROTOR BOW THRUSTER USING EULER-BERNOULLI BEAM MODELING}

Harry Purnama, Budi Noviantoro Fadjrin, Muhammad Ilham Adynugraha, Cuk Supriyadi Ali Nandar

\begin{abstract}
Abstrak
Perkembangan mesin-mesin elektrik terutama Bow Thruster bagi sektor kemaritiman sangat signifikan. Dari beberapa komponen penting dalam Bow Thruster, seperti rotor terutama pada bagian poros dan bantalannya (bearing) mempunyai peran penting sehingga perlu dilakukan analisis. Analisis dinamik merupakan analisis untuk mengetahui sifat-sifat dinamik rotor akibat pengaruh putaran terhadap frekuensi pribadi. Pada makalah ini analisis dinamik dikembangkan dengan pemodelan rotor menggunakan Euler-Bernoulli Beam (EBB) secara numerik dengan perangkat lunak GNU-Octave yang merupakan perangkat lunak open source. Hasil dari analisis dinamik rotor ini menunjukan putaran kritis pada putaran 417, 433, 673, 750 RPM. dan modus getar pada frekuensi 6.904, 7.236, $11.32912 .264 \mathrm{~Hz}$ dari rotor Bow Thruster.
\end{abstract}

Kata kunci : rotor dinamik, Euler-Bernoulli Beam, poros, putaran kritis, modus getar.

\section{MOLD PROPERTIES OF INDONESIA NATURE SAND AS GREEN SAND}

\section{Yusup Hendronursito, Muhammad Amin, Kusno Isnugroho, David C B}

\begin{abstract}
The mould properties of Juwono sand, were investigated. The samples were subjected to various physical and mechanical test. These include permeability, green compression strength, and chemical composition by XRF/ XRD analysis. Green shear strength, grain shape, water content, and clay content were also carried out on the samples. Juwono sand casting containing $32.76 \%$ clay and category in grade $212 / 75$ of fine sub grades were found to posses adequate permeability, good strength and refractoriness suitable for casting of both ferrous and non ferrous alloys.
\end{abstract}

Key Words : sand, physiscal test, mechanical test, refractoriness, casting. 


\title{
PENGARUH PERLAKUAN PELARUTAN TERHADAP SIFAT MEKANIK DAN STRUKTUR MIKRO PADUAN TERNER Zr-Nb-Mo UNTUK BIOMATERIAL
}

\section{EFFECT OF SOLUTION TREATMENT ON MECHANICAL PROPERTIES AND MICRO STRUCTURE TERNARY ALLOY Zr-Nb FOR BIOMATERIAL}

\author{
Dzikry Syamsul Nur Alam, Pradoto Ambardi, Djoko Hadi Prajitno
}

\begin{abstract}
Abstrak
Penelitian dilakukan untuk mempelajari pengaruh perlakuan pelarutan terhadap sifat mekanik dan stuktur mikro paduan terner $\mathrm{Zr}$-Nb-Mo untuk biomaterial. Paduan zirkonium dapat digunakan sebagai bahan implan. Paduan $\mathrm{Zr}-5 \mathrm{Nb}-\mathrm{xMo}(\mathrm{x}=0,1,3$ dan $5 \% \mathrm{wt})$ dilakukan perlakuan pelarutan dengan variasi temperatur $900^{\circ} \mathrm{C}, 950^{\circ} \mathrm{C}$ dan $1000^{\circ} \mathrm{C}$ dengan pendinginan cepat menggunakan medium air. Hasilnya menunjukan bahwa peningkatan kandungan molibdenum, dapat meningkatkan fasa $\beta-\mathrm{Zr}$ dan peningkatan temperatur perlakuan pelarutan dapat meningkatkan kekerasan paduan zirconium. Hal tersebut terjadi karena unsur molibdenum bertindak sebagai beta stabilizer dan perlakuan pelarutan membentuk perubahan bentuk fasa $\beta$-Zr dari plate menjadi lath yang lebih halus. Pengujian kekerasan Rockwell $C$ dengan nilai kekerasan tertinggi 53,67 HRC paduan $\mathrm{Zr}-5 \mathrm{Nb}-1 \mathrm{Mo}$ perlakuan pelarutan $1000^{\circ} \mathrm{C}$, fasa yang terbentuk adalah $\alpha-\mathrm{Zr}, \beta-\mathrm{Zr}$, dan intermetalik $\mathrm{Mo}_{2} \mathrm{Zr}$ paduan Zr-5Nb-5Mo yang diidentifikasi menggunakan $X$-Ray Diffraction (XRD).
\end{abstract}

Kata kunci : Paduan Zr-5Nb-xMo, perlakuan pelarutan, beta stabilizer.

\section{UJI PROFISIENSI ANTAR LABORATORIUM UJI TARIK BAJA TULANGAN SIRIP}

\section{PROFICIENCY TESTING OF TENSION TESTING OF DEFORMED CARBON-STEEL BARS FOR CONCRETE REINFORCEMENT}

\author{
H. Agus Suhartono, Eka Febriyanti
}

\begin{abstract}
Abstrak
Pengukuran sifat mekanik yang akurat merupakan suatu hal yang sangat diperlukan dalam perhitungan kekuatan desain suatu struktur. Uji profisiensi antar laboratorium menjamin keamanan dan kehandalan hasil uji. Laboratorium wajib memverifikasi prosedur pengujian dan kapasitasnya untuk mendapatkan hasil uji yang dapat diandalkan. Dalam penelitian ini, benda uji adalah baja tulangan sirip dengan dimensi yang berbeda. Benda uji yang dipilih secara acak memiliki dimensi tertentu dikirim ke masing-masing laboratorium peserta, kemudian diuji dan hasilnya dianalisis sesuai dengan parameter yang ditetapkan sebelumnya. Setiap laboratorium diterapkan tes tarik pada benda uji sesuai dengan prosedur yang diberikan dalam SNI 2052-2002 dan standar uji tarik yang biasa dipergunakan masing-masing laboratorium. Hasil uji dievaluasi sesuai dengan prosedur yang dijelaskan dalam standar terkait. Hasil yang dikumpulkan dievaluasi sesuai dengan metode statistik Robust kemudian Z-score dari laboratorium peserta disajikan. Batas keberterimaan outlier ditetapkan apabila Z-score $>3$. Hasil uji kuat tarik dan kuat luluh dari salah satu laboratorium merupakan outlier pada perhitungan Z-score antar laboratorium. Untuk parameter elongasi terdapat dua laboratorium yang diperingatkan dengan nilai Zscore diantara 2 dan 3.
\end{abstract}

Kata kunci: baja tulangan beton, uji profisiensi, uji tarik 


\title{
PERANCANGAN DAYA GERAK PERAHU RAWA BERBASIS PROPULSI UDARA GUNA MENINGKATKAN KINERJA WAHANA PATROLI TNI AL
}

\section{SWAMP BOAT AIR PROPULSION BASED POWER DESIGN TO IMPROVE VEHICLE PERFORMANCE OF TNI AL}

\author{
A. Paripurna, Samudro, Suwahyu, R. Kharis, H. Suyanto
}

\begin{abstract}
Abstrak
Perahu Rawa (swamp boat) sebagai wahana taktis patroli militer TNI-AL dapat digunakan di rawa-rawa, perairan dangkal maupun sungai pedalaman. Perahu dirancang berbahan aluminium alloy dengan struktur lambung dasar rata (bottom flat) dilengkapi sistem propulsi berbaling-baling udara sehingga mampu melaju dan olah gerak dengan kecepatan tinggi. Sebagai wahana operasi patroli militer, kinerja perahu rawa perlu ditingkatkan melalui perancangan daya gerak sistem propulsi berbasis perhitungan baling-baling udara dalam kondisi hambatan air pada rancang bangun perahu rawa. Dalam studi ini dihasilkan rancangan secara perhitungan numerik propulsi di air perahu rawa berukuran panjang 5,8 $\mathrm{m}$ dengan bobot 2 Ton, berkecepatan hingga 50 knot, dengan hambatan air 6198,34 $\mathrm{N}$ yang membutuhkan tenaga dorong $267,5 \mathrm{HP}$. Dari evaluasi perbandingan antara perhitungan daya dorong berbasis perhitungan propulsi memakai baling-baling udara (engine propeller thrust) pada efisiensi $80 \%$ dan berbasis perhitungan propulsi di air, maka untuk mencapai kecepatan 50 knot hanya membutuhkan tenaga dorong (thrust) 8921,92 N setara daya dorong 238,1 HP. Oleh karena itu, untuk mengoptimalkan daya dorong sistem propulsi sebagai penggerak perahu pada kecepatan operasi 20 knot yang disyaratkan pada opsrec-spectec, digunakan alternatif mesin diesel dengan tenaga $275 \mathrm{HP} / 2500-3000$ RPM dilengkapi baling-baling udara berbahan komposit diameter 78". Hasil pengujian pelayaran perahu rawa di perairan terbatas menunjukkan hasil peningkatan kinerja kecepatan operasi $50 \%$, dicapai pada pada putaran baling-baling 2362,5 RPM dengan prestasi kecepatan operasi perahu rawa mencapai 30 knot.
\end{abstract}

Kata kunci : Perahu rawa, Hambatan air, Daya dorong, Peningkatan kecepatan operasi

\section{KAJIAN TEKNOLOGI PEMANFAATAN BIOGAS POME (PALM OIL MILL EFFLUENT) KE BOILER}

\section{STUDY OF THE TECHNOLOGY OF UTILIZING BIOGAS FROM PALM OIL MILL EFFLUENT (POME) TO BOILER}

\section{Bambang Sucahyo, Dwi Lukman H, Rohmadi Ridlo, Tyas Puspita R, Erna Rosmala S}

\begin{abstract}
Abstrak
PTPN V di Propinsi Riau, merencanakan kajian teknis untuk penerapan teknologi Biogas to Boiler untuk memaksimalkan pemanfaatan Biogas, khususnya di PKS Sei Pagar. Kajian tersebut bertujuan untuk mensubstitusi Cangkang pada Boiler/ Ketel Uap melalui skema Model Pemanfaatan Biogas POME ke Boiler pada Pabrik Kelapa Sawit. Selain kajian teknis, kajian keekonomian dan lingkungan dilakukan dalam kaitan studi banding ke beberapa PKS di wilayah Sumatera dan Kalimantan. Skema Model Pemanfaatan Biogas POME ke Boiler pada Pabrik Kelapa Sawit menggunakan beberapa komponen, seperti : Blower, Sistem Pemipaan, Valve Train, Gas Burner (Single Burner), Forced Draft Fan, dan Control Panel (PHB). Dari hasil studi tersebut, jumlah cangkang yang dapat digantikan dengan biogas POME pada pembakaran di Boiler sebanyak $6.549,3$ ton per tahun. Jika cangkang tersebut dapat dijual dengan harga sebesar Rp 4.000 per $\mathrm{kg}$ atau Rp 400.000 per ton, maka pendapatan yang diperoleh dari hasil penjualan cangkang sekitar Rp 2,62 Milyar. Model Pemanfaatan tersebut dapat dikembangkan dan diterapkan untuk mendukung penerapan teknologi Biogas to Boiler di Pabrik Kelapa Sawit yang ada di Indonesia.
\end{abstract}

Kata Kunci : Ketel Uap/ Boiler, Blower, Sistem Pemipaan, Valve Train, Gas Burner (Single Burner), Forced Draft Fan, Control Panel 


\title{
KAJIAN EKSPERIMENTAL PELUNCURAN KAPAL MENGGUNAKAN AIR BAG
}

\section{EXPERIMENTAL STUDY ON SHIP LAUNCHING USING AIRBAGS}

\author{
Zulis Irawanto ${ }^{a}$, Navik Puryantini ${ }^{a}$, Baharudin Alia ${ }^{a}$ Budi Setyo Prasodjo ${ }^{b}$
}

\begin{abstract}
Abstrak
Makalah ini melaporkan hasil penelitian di Balai Teknologi Hidrodinamika yang mengkaji peluncuran kapal dengan menggunakan air bag. Metode yang digunakan adalah uji model dengan melakukan studi sensitivitas beberapa parameter yang berpengaruh pada peluncuran kapal. Analisis dilakukan pada beberapa kondisi ekstrim yaitu kondisi terjadinya benturan, kondisi pada sudut pitch maksimum, dan kondisi pada freeboard minimum. Melalui uji model, dapat diketahui perilaku gerakan kapal saat diluncurkan dengan menggunakan air bag, serta dapat diketahui tingkat keselamatan peluncuran kapal.
\end{abstract}

Kata kunci: Peluncuran kapal, Air bag, Uji model

\section{SIMULASI BEBAN JALAN DAN TRAKSI RODA PADA PEMILIHAN ROLLING CHASSIS 4WD UNTUK KENDARAAN WATER CANNON}

\section{ROAD LOAD AND WHEEL TRACTION SIMULATION OF 4WD ROLLING CHASSIS SELECTION FOR WATER CANNON VEHICLE}

\author{
Prasetyaning Diah Rizky Lestari, Agus Sartomo, Taufik Yuwono
}

\begin{abstract}
Abstrak
Tingkat kandungan dalam negeri (TKDN) pada kendaraan taktis Water Cannon (WCV) milik Polri yang rendah mendorong adanya kajian yang mengarah pada peningkatan nilai TKDN. Salah satu penguasaan teknologi dalam pengembangan kendaraan taktis yaitu dengan memilih beberapa komponen tertentu dari kendaraan yang mempunyai daya ungkit tinggi dalam meningkatkan TKDN hingga mencapai 25\% atau lebih. Dalam kajian ini komponen yang dipilih yaitu berupa rolling chassis kendaraan. Sesuai dengan spesifikasi kendaraan WCV Tactica milik Polri maka pada kajian ini dipilih WCV 4WD dengan tujuan kendaraan dapat digunakan di medan jalan tanah dan lincah dalam bermanuver. Rolling chassis akan dipilih berdasarkan hasil simulasi performanya berdasarkan beban jalan kendaraan dan traksi roda yang dihasilkan. Simulasi perhitungan dilakukan dengan menggunakan 3 macam merek rolling chassis 4 WD yaitu $A, B$ dan $C$ yang tersedia di pasaran lokal Indonesia. Tinjauan utama dalam membandingkan 3 merek rolling chassis ini adalah kemampuan tanjaknya serta kecepatan yang dapat dicapai pada kemampuan tanjak tersebut. Dari hasil kajian disimpulkan bahwa secara keseluruhan desain kendaraan WCV dengan menggunakan rolling chassis merek B lebih layak digunakan. Dengan rolling chassis merek B, kendaraan WCV dapat melalui tanjakan hingga $30^{\circ}$ dengan kecepatan maksimal $9 \mathrm{~km} / \mathrm{jam}$. Simulasi beban jalan kendaraan dan traksi roda ini dapat digunakan sebagai salah satu metode acuan pemilihan rolling chassis untuk kendaraan WCV.
\end{abstract}

Kata kunci : Traksi, Beban Jalan Kendaraan, Rolling Chassis, Water Cannon Vehicle 


\title{
ANALISIS KEEKONOMIAN PEMBANGUNAN PEMBANGKIT LISTRIK TENAGA BIOGAS DARI POME DENGAN CONTINUOUS STIRRED TANK REACTOR (CSTR)
}

\section{ECONOMIC ANALYSIS FOR THE DEVELOPMENT OF POME BIOGAS POWER PLANT USING CONTINUOUS STIRRED TANK REACTOR (CSTR)}

\author{
Agus Sugiyono, Adiarso, Ratna Etie Puspita Dewi, Yudiartono, \\ Agung Wijono, dan Niken Larasati
}

\begin{abstract}
Abstrak
Limbah cair kelapa sawit atau dikenal dengan POME (palm oil mill effluent) dapat diproses menjadi biogas sebagai bahan bakar untuk pembangkit listrik. Produksi POME saat ini dapat digunakan untuk pembangkit listrik tenaga biogas (PLTBg) dengan kapasitas mencapai 153,4 MW yang sebagian besar berada di wilayah Sumatera. Salah satu pabrik kelapa sawit (PKS) yang berpotensi untuk pembangunan PLTBg adalah PKS Sei Pagar milik PTPN V Pekanbaru. Studi ini bertujuan untuk melakukan analisis keekonomian pembangunan PLTBg. PLTBg didesain dengan kapasitas $700 \mathrm{~kW}$ dengan menggunakan biodigester jenis continuous stirred tank reactor (CSTR). Listrik yang dihasilkan akan dijual ke PLN dengan harga jual sebesar $85 \%$ biaya pokok penyediaan (BPP) pembangkitan wilayah Riau sebesar 1.249,5 Rp/kWh. Hasil perhitungan keekonomian menunjukkan bahwa biaya investasi mencapai 26,3 miliar Rupiah dengan skema $70 \%$ pinjaman dari bank dan sisanya $30 \%$ dengan modal sendiri (equity). Biaya operasi dan perawatan mencapai 2,3 miliar Rupiah setiap tahun. Pembangunan PLTBg layak untuk dilaksanakan dengan nilai IRR sebesar 11,44\%, waktu pengembalian modal selama 7 tahun 11 bulan, dan NPV sebesar 1.1 miliar Rupiah.
\end{abstract}

Kata kunci : POME, CSTR, PLTBg, studi kelayakan.

\section{BINOMIAL LOGIT MODEL UNTUK PEMILIHAN MODA ANTARA PESAWAT UDARA, KERETA API EKSEKUTIF DAN KERETA API EKSPRES}

\section{BINOMIAL LOGIT MODEL FOR SELECTING MODA BETWEEN AIRCRAFT, EXECUTIVE TRAIN AND EXPRESS TRAIN}

\author{
Djoko Prijo Utomo, Mulyadi Sinung Harjono
}

\begin{abstract}
Abstrak
Penelitian ini dilakukan untuk mengkaji potensi pasar rencana pembangunan kereta api ekspres Jakarta - Semarang. Survei stated preference dan model logit binomial digunakan untuk mengidentifikasi kompetisi antara moda kereta api ekspres dengan pesawat udara maupun kereta api kelas eksekutif yang telah beroperasi. Atribut yang digunakan adalah travel time dan travel cost. Hasil analisis regresi untuk model utility cukup baik dengan indikator $\mathrm{R}^{2}$ sebesar 0,51 untuk penumpang pesawat udara dan 0,56 untuk penumpang kereta api kelas api eksekutif. Hasil temuan menunjukkan bahwa penumpang pesawat udara lebih sensitif terhadap perubahan waktu tempuh dibandingkan penumpang kereta api (KA) eksekutif, dan penumpang pesawat udara juga memiliki kemampuan membeli yang lebih tinggi dibandingkan penumpang KA eksekutif. Jika waktu perjalanan KA ekspres 2,8 jam (kecepatan rata-rata $155,5 \mathrm{~km} / \mathrm{jam})$, maka potensi pendapatan terbesar terjadi jika tarif Rp. 360.000,-/penumpang.
\end{abstract}

Kata kunci : Kereta Api, potensi permintaan, Stated Preference, Binomial Logit Model 